\title{
КЛІНІКО-ЛАБОРАТОРНА ХАРАКТЕРИСТИКА КОМОРБІДНОГО ПЕРЕБІГУ ЦУКРОВОГО ДІАБЕТУ 2 ТИПУ 3 НАДМІРНОЮ МАСОЮ ТІЛА/ОЖИРІННЯМ ТА АРТЕРІАЛЬНОЮ ГІПЕРТЕНЗІЄЮ
}

Вступ. Артеріальна гіпертензія (АГ) є основною причиною захворюваності та смертності серед пацієнтів із цукровим діабетом 2 типу (ЦД2), що пов'язано із серцево-судинними захворюваннями.

Мета дослідження - проаналізувати основні клініко-лабораторні фрактори коморбідного перебігу цукрового діабету 2 типу з надмірною масою тіла/ожирінням та артеріальною гіпертензією.

Методи дослідження. Ретроспективний аналіз медичної документації проведено в 579 хворих на цукровий діабет 2 типу (T2DM). Концентрацію глюкози та інших біохімічних показників визначали з використанням стандартного набору на автоматичному біохімічному аналізаторі "COBAS INTEGRA® 400" ("Roche Diagnostics"). Показники загального аналізу крові визначали на автоматичному гематологічному аналізаторі "Yumizen H50O CT".

Результати й обговорення. При проведенні аналізу рангових варіацій Краскела - Уолліса не виявлено цінності показників загального аналізу крові та загального аналізу сечі в діагностиці коморбідного перебігу цД2, надмірної маси тіла/ожиріння та АГ. Під час аналізу біохімічних параметрів встановлено найвищі рівні сечовини і сечової кислоти у хворих на ЦД2, ожиріння та АГ. Аналіз показників вуглеводного обміну показав, що рівні глюкози, інсуліну та індекс НОМА у крові пацієнтів різних дослідних груп вірогідно різнилися при проведенні аналізу рангових варіацій Краскела - Уолліса.

Висновки. Під час аналізу статевого диморфрізму встановлено переважання осіб жіночої статі з коморбідним перебігом цукрового діабету 2 типу з надмірною масю тіла/ожирінням та артеріальною гіпертензією. При цьому серед хворих на цукровий діабет 2 типу з коморбідною артеріальною гіпертензією виявлено вірогідно вищий відсоток хворих чоловіків з нормальною масою тіла. При аналізі антропометричних показників пацієнтів різних груп встановлено, що у пацієнтів 6-ї групи зріст був вірогідно меншим стосовно даних у хворих на цукровий діабет 2 типу з нормальною масою тіла та при поєднанні з артеріальною гіпертензією. Індекс маси тіла був достовірно вищим у пацієнтів з надмірною масою тіла/ожирінням. У хворих з коморбідним перебігом цукрового діабету 2 типу з надмірною масою тіла/ожирінням та артеріальною гіпертензією встановлено вірогідно вищі рівні сечовини (на 24,4 \%) та сечової кислоти (на 93,0 \%) щодо даних у пацієнтів із Цд2 та нормальною масою тіла.

КЛЮЧОВІ СЛОВА: цукровий діабет 2 типу; надмірна маса тіла/ожиріння; артеріальна гіпертензія; коморбідність; гемограма; загальний аналіз сечі; біохімічні параметри.

ВСТУП. Цукровий діабет 2 типу (ЦД2) асоціюється з високим ризиком ранньої смертності та захворюваності через серцево-судинні захворювання, такі, як артеріальна гіпертензія (АГ), інсульт і термінальна стадія ниркової недостатності. Артеріальна гіпертензія $€$ основною причиною захворюваності та смертності серед пацієнтів із ЦД2, що пов'язано із серцево-судинними захворюваннями [1-3]. Коморбідність ЦД2 та АГ зростає в усьому світі [4]. Артеріальна гіпертензія із цукровим діабетом 2 типу збільшує ризик смертності в 7,2 раза в країнах, що розвиваються [5], а також сприяє розвитку і прогресуванню мікросудинних (ретинопатія, несрропатія та нейропатія) і макросудинних (атеросклеро(c) І. В. Вівсяна, М. І. Марущак, 2021. тичних) ускладнень ЦД2 через структурні зміни мікроциркуляції внаслідок оксидативного стресу, запалення або ендотеліальної диссрункції [6]. Ушкодження органів, викликане АГ, проявляється підвищенням екскреції альбуміну (протеїнурією), гіпертрофією лівого шлуночка та наявністю змін на ЕКГ $[7,8]$.

Мета дослідження - проаналізувати основні клініко-лабораторні фрактори коморбідного перебігу цукрового діабету 2 типу з надмірною масою тіла/ожирінням та артеріальною гіпертензією.

МЕТОДИ ДОСЛІДЖЕННЯ. Ретроспективний аналіз медичної документації проведено в 579 хворих на цукровий діабет 2 типу, які перебували на стаціонарному лікуванні в ендокрино- 
логічному відділенні Тернопільської університетської лікарні у 2018-2019 рр. Їх поділили на 6 дослідних груп залежно від наявності надмірної маси тіла (Надм МТ)/ожиріння (Ож) та АГ. Розподіл груп показано в таблиці 1.

Верифрікацію ЦД2 проводили відповідно до рекомендацій Американської діабетичної асоціації (2019) [9]. Критерії діагностики ЦД2 базувалися на значенні глікованого гемоглобіну (HbA1c) ( $\geq 6,5 \%$ ), який визначали за допомогою автоматичного біохімічного аналізатора "COBAS 6000" ("Roche Hitachi", Німеччина). Концентрацію глюкози та інших біохімічних показників визначали з використанням стандартного набору на автоматичному біохімічному аналізаторі "COBAS INTEGRA® 400" ("Roche Diagnostics"). Рівень інсуліну в крові визначали на імуноферментному аналізаторі "Thermo Scientific Multiskan FC". Iнсулінорезистентність оцінювали за індексом HOMA (Homeostasis Model Assessment for Insulin Resistance), який вираховували за фрормулою: HOMA = (глюкоза плазми натще, ммоль/л $\times$ iнсулін плазми натще, мкМО/мл) / 22,5. Показники загального аналізу крові визначали на автоматичному гематологічному аналізаторі "Yumizen H500 CT".

Діагноз артеріальної гіпертензії 1-ї стадії встановлювали згідно з рекомендаціями ESC/ ESH 3 АГ 2018 р., які представили на конгресі Європейського товариства кардіологів (ESC) [10]. Гіпертрофрію лівого шлуночка підтверджували електрокардіографрічно.

Індекс маси тіла (IMT) розраховували за фрормулою: ІМТ = маса тіла (кг) / зріст (м²). Дані інтерпретували відповідно до рекомендацій ВОО3: нормальна маса тіла - в межах 20,0-24,9 кг/м²; надмірна маса тіла (передожиріння) - 25,0-

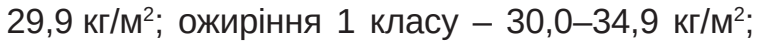

ожиріння 2 класу - 35,0-39,9 кг/м²; ожиріння

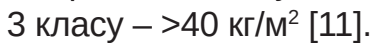

Статистичну обробку результатів проводили $з$ використанням комп'ютерної програми STATISTICA 7.0. Вибір методу статистичного дослідження базувався на правильності розподілу досліджуваних ознак.

Зважаючи на неправильний розподіл кількісних характеристик, їх описову статистику здійснювали у вигляді розрахунку медіани (Ме) і нижнього (Lq) та верхнього (Uq) квартилів.

Порівняльний аналіз кількісних показників у трьох і більше групах проводили із застосуванням критерію Краскела - Уолліса, який вважали статистично значущим при його значеннях $\mathrm{p}<0,05$. Подальше попарне порівняння груп здійснювали з використанням U-критерію Манна - Уїтні з урахуванням поправки Бонферроні при оцінюванні рівня статистичної значущості.

РЕЗУЛЬТАТИ Й ОБГОВОРЕННЯ. За ВікОВИМ аспектом між дослідними групами хворих істотної різниці не було (табл. 2).

Ризик коморбідного перебігу ЦД2 та АГ у віці понад 50 років підтвердили дослідження ряду вчених [12-14]. Це може бути пов'язано зі змінами судин під час старіння. 3 віком ущільнення та потовщення артерій будуть спровоковані складною зміною кожного шару кровоносних судин [15]. Потовщення інтими, викликане старінням, порушує цілісність ендотелію і зменшує доступність та ефективність судинорозширювальних засобів, таких, як оксид азоту [16]. Зміцнення стінок артерій порушує нормальний кровотік, створюючи сприятливі умови для накопичення кальцію та жирових відкладень на внутрішній стороні артерій, що збільшує звуження артерій і викликає АГ [6, 17].

Таблиця 1 - Групи хворих на цукровий діабет 2 типу

\begin{tabular}{||c|c|c|c||}
\hline \hline \multicolumn{2}{|c|}{ Група хворих } & $\mathrm{n}$ & $\%$ \\
\hline 1-ша & ЦД2+Норм МТ & 39 & 6,74 \\
\hline 2-га & ЦД2+Надм МТ & 33 & 5,70 \\
\hline 3-тя & ЦД2+Ож & 22 & 3,80 \\
\hline 4-та & ЦД2+Норм МТ+АГ & 59 & 10,19 \\
\hline $5-т а$ & ЦД2+Надм МТ+АГ & 131 & 22,63 \\
\hline 6-та & ЦД2+Ож+АГ & 295 & 50,95 \\
\hline
\end{tabular}

Таблиця 2 - Вік обстежених хворих на цукровий діабет 2 типу, включених у дослідження

\begin{tabular}{||c|c|c||}
\hline \hline \multicolumn{2}{|c|}{ Група хворих } & Вік, роки \\
\hline 1-ша & ЦД2+Норм МТ $(\mathrm{n}=39)$ & $51,00 \pm 10,31$ \\
\hline 2-га & ЦД2+Надм МТ $(\mathrm{n}=33)$ & $53,42 \pm 12,80$ \\
\hline 3-тя & ЦД2+Ож $(\mathrm{n}=22)$ & $51,27 \pm 10,15$ \\
\hline 4-та & ЦД2+Норм МТ+АГ $(\mathrm{n}=59)$ & $56,36 \pm 10,23$ \\
\hline $5-т а$ & ЦД2+Надм МТ+АГ $(\mathrm{n}=131)$ & $57,67 \pm 8,94$ \\
\hline 6-та & ЦД2+Ож+АГ $(\mathrm{n}=295)$ & $56,89 \pm 8,51$ \\
\hline
\end{tabular}

Примітка. р<0,05 при порівнянні 1-5, 1-6, 3-5 груп. 
При аналізі статевого диморфрізму серед пацієнтів, включених у дослідження, встановлено переважання чоловіків у 1-4 дослідних групах, тоді як жінки переважали в 5-й і 6-й дослідних групах (табл. 3). При цьому серед хворих на ЦД2 3 коморбідною АГ виявлено вірогідно вищий відсоток хворих чоловіків з нормальною масою тіла та жінок з ожирінням.

При аналізі антропометричних показників хворих різних груп встановлено, що у пацієнтів 6-ї групи зріст був вірогідно меншим стосовно даних х хворих на ЦД2 з нормальною масою тіла та ЦД2 з нормальною масою тіла в поєднанні 3 АГ. Індекс маси тіла був достовірно вищим у пацієнтів 3 надмірною масою тіла/ожирінням (табл. 4).

Надмірна маса тіла $€$ найсильнішим фактором ризику розвитку цД2 в осіб обох статей [18]. Однак "поріг", при якому розвивається резистентність до інсуліну, відрізняється залежно від етнічної приналежності, спадковості й статі [19]. Жінки захищені від більш високого IMT, оскільки вони накопичують ліпіди в підшкірній жировій клітковині, це завдає меншої шкоди, ніж при накопиченні їх у вісцеральній жировій тканині, що спостерігають у чоловіків [20].

Інсулінорезистентність і ЦД2 асоціюються 3 підвищеним ризиком розвитку серцево-судинних захворювань, до 50 \% частіше у жінок, ніж у чоловіків [21]. Імовірно, ЦД2 нівелює захисний есрект естрогену [22]. Ризик розвитку серцево-су- динних захворювань зростає щонайменше в 3-6 разів у жінок із ЦД2, тоді як у чоловіків із цукровим діабетом - у 2-4 рази [23].

Серед ускладнень ЦД2 у хворих усіх дослідних груп переважала полінейропатія (табл. 5). 3 іншого боку, ангіопатію сітківки вірогідно частіше діагностували у пацієнтів із ЦД2 та нормальною масою тіла стосовно даних 3-ї і 4-ї дослідних груп. Також частота ангіопатій сітківки була достовірно вищою у хворих на ЦД2 з надмірною масою тіла щодо даних 3-ї і 5-ї дослідних груп. Непролісреративну ретинопатію найчастіше виявляли у пацієнтів 4-6 дослідних груп. Частота полінейропатій, як і енцефалопатій, була вірогідно більшою у хворих 5-ї групи стосовно даних 2-ї групи та у пацієнтів 6-ї групи порівняно з даними 3-ї групи. Поширеність мікро- та макроангіопатій була достовірно вищою у хворих на ЦД2 з надмірною масою тіла й АГ щодо пацієнтів із Цд2 з надмірною масою тіла. Діабетичну несрропатію у хворих на ЦД2 з надмірною масою тіла діагностували значно рідше стосовно даних 3-ї і 5-ї дослідних груп (табл. 5).

Встановлено, що показники гемограми у крові пацієнтів різних дослідних груп вірогідно не різнилися при проведенні аналізу рангових варіацій Краскела - Уолліса, що вказує на відсутність діагностичної цінності загального аналізу крові у хворих з коморбідним перебігом ЦД2 3 надмірною масою тіла/ожирінням та АГ (табл. 6).

Таблиця 3 - Статевий розподіл хворих на цукровий діабет 2 типу, включених у дослідження

\begin{tabular}{|c|c|c|c|c|c|c|}
\hline \multirow{2}{*}{\multicolumn{2}{|c|}{ Група хворих }} & \multicolumn{2}{|c|}{ Чоловіки } & \multicolumn{2}{|r|}{ Жінки } & \multirow{2}{*}{$x^{2}, p$} \\
\hline & & $\mathrm{n}$ & \% (95 \% ДI) & $\mathrm{n}$ & \% (95 \% ДІ) & \\
\hline 1-ша & ЦД2+Норм МТ (n=39) & 30 & 76,92 & 9 & 23,08 & \multirow{6}{*}{$\begin{array}{l}x^{2}=23,16 ; \\
p<0,001^{*} \\
p_{4-6}<0,01^{*}\end{array}$} \\
\hline 2-га & ЦД2+Надм МТ (n=33) & 19 & 57,58 & 14 & 42,42 & \\
\hline 3-тя & ЦД2+Ож (n=22) & 13 & 59,09 & 9 & 40,91 & \\
\hline 4-та & ЦД2+Норм МТ+АГ (n=59) & 36 & 61,02 & 23 & 38,98 & \\
\hline 5-та & ЦД2+Надм МТ+АГ (n=131) & 60 & 45,80 & 71 & 54,20 & \\
\hline 6-та & ЦД2+Ож+АГ (n=295) & 125 & 42,37 & 170 & 57,63 & \\
\hline
\end{tabular}

Примітка. Тут і в таблицях 5, 8: * - достовірні результати.

Таблиця 4 - Антропометричні показники хворих на цукровий діабет 2 типу, включених у дослідження

\begin{tabular}{||c|c|c|c|c|}
\hline \hline \multicolumn{2}{|c|}{ Група хворих } & Маса тіла & 3ріст & Індекс маси тіла \\
\hline 1-ша & ЦД2+Норм МТ $(\mathrm{n}=39)$ & $65,08 \pm 9,92$ & $171,82 \pm 8,95$ & $21,93 \pm 2,16$ \\
\hline 2-га & ЦД2+Надм МТ $(\mathrm{n}=33)$ & $79,91 \pm 9,42$ & $171,56 \pm 9,72$ & $27,09 \pm 1,69$ \\
\hline 3-тя & ЦД2+Ож $(\mathrm{n}=22)$ & $105,32 \pm 18,24$ & $173,55 \pm 8,96$ & $34,95 \pm 5,99$ \\
\hline 4-та & ЦД2+Норм МТ+АГ $(\mathrm{n}=59)$ & $67,13 \pm 8,14$ & $170,95 \pm 8,96$ & $22,96 \pm 1,39$ \\
\hline 5-та & ЦД2+Надм МТ+АГ $(\mathrm{n}=131)$ & $80,01 \pm 8,73$ & $169,32 \pm 8,12$ & $27,81 \pm 1,31$ \\
\hline 6-та & ЦД2+Ож+АГ $(\mathrm{n}=295)$ & $99,32 \pm 17,71$ & $167,64 \pm 8,07$ & $35,27 \pm 5,24$ \\
\hline
\end{tabular}

Примітки:

1. Маса тіла - p<0,05 при порівнянні різних за нутритивним статусом груп.

2. Зріст - р<0,05 при порівнянні 1-6 та 3-6 груп.

3. Індекс маси тіла - p<0,05 для всіх груп, за винятком порівняння груп з Норм МТ (1-4). 


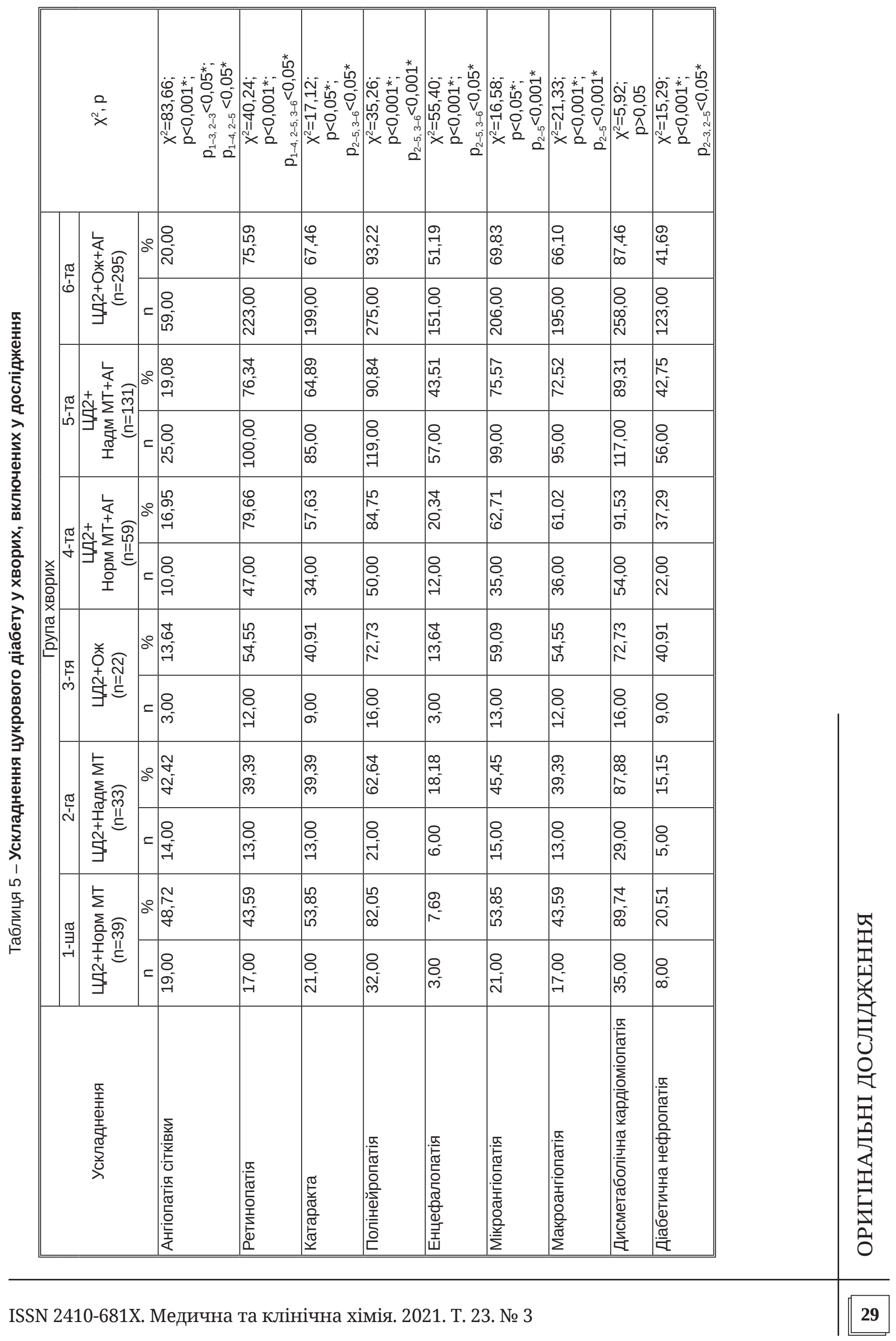


При проведенні аналізу рангових варіацій Краскела - Уолліса не виявлено цінності показників загального аналізу сечі в діагностиці коморбідного перебігу цД2, надмірної маси тіла/ ожиріння та АГ (табл. 7).

Встановлено, що серед показників біохімічного аналізу крові рівні загального білірубіну, сечовини та сечової кислоти у крові пацієнтів різних дослідних груп вірогідно різнилися при проведенні аналізу рангових варіацій Краскела Уолліса. При цьому концентрація загального білірубіну була найнижчою у хворих 4-ї групи, вона вірогідно відрізнялася на 37,3 \% стосовно пацієнтів 6-ї дослідної групи. Рівень сечовини

Таблиця 6 - Показники гемограми у хворих на цукровий діабет 2 типу в поєднанні 3 надмірною масою тіла/ожирінням та артеріальною гіпертензією

\begin{tabular}{|c|c|c|c|c|c|c|c|}
\hline \multirow[b]{3}{*}{ Показник } & \multicolumn{6}{|c|}{ Група хворих } & \multirow[b]{3}{*}{$\begin{array}{l}\text { Критерій } \\
\text { Краскела - } \\
\text { Уолліса }\end{array}$} \\
\hline & 1-ша & 2-га & 3-тя & 4-та & 5-та & 6-та & \\
\hline & $\begin{array}{c}\text { ЦД2+ } \\
\text { Норм МТ } \\
(n=39)\end{array}$ & $\begin{array}{c}\text { Цд2+ } \\
\text { Надм Мт } \\
(\mathrm{n}=33)\end{array}$ & $\begin{array}{l}\text { ЦД2+Ож } \\
(\mathrm{n}=22)\end{array}$ & $\begin{array}{c}\text { ЦД2+ } \\
\text { Норм МТ+ } \\
\text { АГ } \\
(\mathrm{n}=59)\end{array}$ & $\begin{array}{c}\text { ЦД2+ } \\
\text { Надм МТ+ } \\
\text { АГ } \\
(\mathrm{n}=131)\end{array}$ & $\begin{array}{c}\text { ЦД2+ } \\
\text { Ож+АГ } \\
(n=295)\end{array}$ & \\
\hline Гемоглобін, г/л & $\begin{array}{c}136 \\
(122 ; 149) \\
\end{array}$ & $\begin{array}{c}144 \\
(125 ; 150) \\
\end{array}$ & $\begin{array}{c}139 \\
(130 ; 155) \\
\end{array}$ & $\begin{array}{c}137 \\
(126 ; 149) \\
\end{array}$ & $\begin{array}{c}138 \\
(127 ; 152) \\
\end{array}$ & $\begin{array}{c}137 \\
(126 ; 146) \\
\end{array}$ & $\begin{array}{l}H=4,01 ; \\
p>0,05\end{array}$ \\
\hline $\begin{array}{l}\text { Еритроцити, } \\
\times 10^{12} л\end{array}$ & $\begin{array}{c}4,20 \\
(3,90 ; 4,62) \\
\end{array}$ & $\begin{array}{c}4,43 \\
(3,90 ; 4,70)\end{array}$ & $\begin{array}{c}4,45 \\
(4,18 ; 4,65) \\
\end{array}$ & $\begin{array}{c}4,40 \\
(3,98 ; 4,70)\end{array}$ & $\begin{array}{c}4,38 \\
(4,00 ; 4,70)\end{array}$ & $\begin{array}{c}4,32 \\
(4,00 ; 4,60)\end{array}$ & $\begin{array}{l}H=3,20 \\
p>0,05\end{array}$ \\
\hline $\begin{array}{l}\text { Кольоровий } \\
\text { показник }\end{array}$ & $\begin{array}{c}0,9 \\
(0,9 ; 1,0)\end{array}$ & $\begin{array}{c}0,9 \\
(0,9 ; 1,0)\end{array}$ & $\begin{array}{c}0,9 \\
(0,9 ; 1,0)\end{array}$ & $\begin{array}{c}0,9 \\
(0,9 ; 1,0)\end{array}$ & $\begin{array}{c}0,9 \\
(0,9 ; 1,0)\end{array}$ & $\begin{array}{c}0,9 \\
(0,9 ; 1,0)\end{array}$ & $\begin{array}{l}\mathrm{H}=4,52 \\
\mathrm{p}>0,05\end{array}$ \\
\hline $\begin{array}{l}\text { Швидкість } \\
\text { осідання еритро- } \\
\text { цитів, мм/год }\end{array}$ & $8(5 ; 18)$ & $12(6 ; 19)$ & $17(8 ; 25)$ & $10(7 ; 22)$ & $12(6 ; 23)$ & $14(8 ; 22)$ & $\begin{array}{l}\mathrm{H}=10,04 \\
\mathrm{p}>0,05\end{array}$ \\
\hline Лейкоцити, ×1097л & $\begin{array}{c}6,8 \\
(4,8 ; 9,0) \\
\end{array}$ & $\begin{array}{c}6,5 \\
(5,0 ; 7,4) \\
\end{array}$ & $\begin{array}{c}6,3 \\
(5,7 ; 7,9) \\
\end{array}$ & $\begin{array}{c}5,8 \\
(5,1 ; 7,0) \\
\end{array}$ & $\begin{array}{c}6,3 \\
(4,8 ; 7,3) \\
\end{array}$ & $\begin{array}{c}6,4 \\
(5,3 ; 7,8) \\
\end{array}$ & $\begin{array}{l}H=6,81 ; \\
p>0,05\end{array}$ \\
\hline $\begin{array}{l}\text { Паличкоядерні } \\
\text { нейтрофріли, \% }\end{array}$ & $5(3 ; 8)$ & $5(4 ; 7)$ & $6(5 ; 7)$ & $5(3 ; 7)$ & $4(3 ; 6)$ & $4(3 ; 6)$ & $\begin{array}{l}H=8,87 ; \\
p>0,05\end{array}$ \\
\hline $\begin{array}{l}\text { Сегментоядерні } \\
\text { нейтросріли, \% }\end{array}$ & $55(49 ; 63)$ & $57(50 ; 62)$ & $59(55 ; 59)$ & $61(55 ; 67)$ & $59(51 ; 65)$ & $57(50 ; 64)$ & $\begin{array}{l}H=7,20 \\
p>0,05\end{array}$ \\
\hline Нейтрофріли, \% & $62(54 ; 69)$ & $63(57 ; 68)$ & $63(59 ; 68)$ & $66(59 ; 72)$ & $64(56 ; 70)$ & $62(55 ; 69)$ & $\begin{array}{c}H=6,35 \\
p>0,05\end{array}$ \\
\hline Еозиносріли, \% & $2(1 ; 3)$ & $2(1 ; 3)$ & $2(1 ; 2)$ & $1(1 ; 3)$ & $2(1 ; 3)$ & $2(1 ; 3)$ & $\begin{array}{l}H=2,61 ; \\
p>0,05\end{array}$ \\
\hline Базофріли, \% & $1(0 ; 1)$ & $1(0 ; 1)$ & $2(1 ; 2)$ & $1(0 ; 2)$ & $1(1 ; 1)$ & $1(1 ; 1)$ & $\begin{array}{l}H=9,55 \\
p>0,05\end{array}$ \\
\hline Лімсроцити, \% & $30(25 ; 38)$ & $34(27 ; 37)$ & $32(28 ; 34)$ & $30(25 ; 38)$ & $31(25 ; 40)$ & $32(25 ; 39)$ & $\begin{array}{c}\mathrm{H}=1,41 \\
\mathrm{p}>0,05\end{array}$ \\
\hline Моноцити, \% & $4(1 ; 5)$ & $4(2 ; 7)$ & $3(3 ; 4)$ & $2(1 ; 4)$ & $4(2 ; 5)$ & $3(2 ; 5)$ & $\begin{array}{l}\mathrm{H}=7,95 ; \\
p>0,05\end{array}$ \\
\hline $\begin{array}{l}\text { Співвідношення } \\
\text { кількості нейтро- } \\
\text { фрілів до кількості } \\
\text { лімороцитів }\end{array}$ & $\begin{array}{c}2,16 \\
(1,51 ; 2,60)\end{array}$ & $\begin{array}{c}1,94 \\
(1,54 ; 2,88)\end{array}$ & $\begin{array}{c}2,02 \\
(1,77 ; 2,43)\end{array}$ & $\begin{array}{c}2,21 \\
(1,55 ; 2,85)\end{array}$ & $\begin{array}{c}2,07 \\
(1,43 ; 2,73)\end{array}$ & $\begin{array}{c}1,94 \\
(1,43 ; 2,67)\end{array}$ & $\begin{array}{l}\mathrm{H}=2,41 ; \\
\mathrm{p}>0,05\end{array}$ \\
\hline
\end{tabular}

Таблиця 7 - Показники загального аналізу сечі у хворих на цукровий діабет 2 типу в поєднанні 3 надмірною масою тіла/ожирінням та артеріальною гіпертензією

\begin{tabular}{|c|c|c|c|c|c|c|c|}
\hline \multirow[b]{3}{*}{ Показник } & \multicolumn{6}{|c|}{ Група хворих } & \multirow[b]{3}{*}{$\begin{array}{l}\text { Критерій } \\
\text { Краскела - } \\
\text { Уолліса }\end{array}$} \\
\hline & 1-ша & 2-га & 3-тя & 4-та & 5-та & 6-та & \\
\hline & $\begin{array}{c}\text { Цд2+ } \\
\text { Норм МТ } \\
(\mathrm{n}=39)\end{array}$ & $\begin{array}{c}\text { Цд2+ } \\
\text { Надм Мт } \\
(\mathrm{n}=33)\end{array}$ & $\begin{array}{l}\text { ЦД2+Ож } \\
(\mathrm{n}=22)\end{array}$ & $\begin{array}{c}\text { ЦД2+ } \\
\text { Норм МТ+ } \\
\text { АГ } \\
(n=59)\end{array}$ & $\begin{array}{c}\text { ЦД2+ } \\
\text { Надм МТ+ } \\
\text { АГ } \\
(\mathrm{n}=131)\end{array}$ & $\begin{array}{c}\text { ЦД2+ } \\
\text { Ож+АГ } \\
(n=295)\end{array}$ & \\
\hline Питома вага & $\begin{array}{l}1020 \\
(1015 ; \\
1025)\end{array}$ & $\begin{array}{l}1019 \\
(1012 ; \\
1029)\end{array}$ & $\begin{array}{l}1017 \\
(1012 ; \\
1026)\end{array}$ & $\begin{array}{c}1018 \\
(1014 ; \\
1022)\end{array}$ & $\begin{array}{c}1020 \\
(1016 ; \\
1024)\end{array}$ & $\begin{array}{l}1020 \\
(1015 ; \\
1024)\end{array}$ & $\begin{array}{c}H=4,63 \\
p>0,05\end{array}$ \\
\hline Білок у сечі, г/л & $\begin{array}{c}0,29 \\
(0,17 ; 0,35)\end{array}$ & $\begin{array}{c}0,15 \\
(0,14 ; 0,22)\end{array}$ & $\begin{array}{c}0,12 \\
(0,10 ; 0,13)\end{array}$ & $\begin{array}{c}0,17 \\
(0,12 ; 0,37)\end{array}$ & $\begin{array}{c}0,17 \\
(0,13 ; 0,33)\end{array}$ & $\begin{array}{c}0,17 \\
(0,11 ; 0,29)\end{array}$ & $\begin{array}{l}H=9,05 \\
p>0,05\end{array}$ \\
\hline Цукор у & $\begin{array}{c}2 \\
(1 ; 2)\end{array}$ & $\begin{array}{c}2 \\
(1 ; 2)\end{array}$ & $\begin{array}{c}2 \\
(1 ; 2)\end{array}$ & $\begin{array}{c}2 \\
(1 ; 2)\end{array}$ & $\begin{array}{c}2 \\
(1 ; 2)\end{array}$ & $\begin{array}{c}1 \\
(1 ; 2)\end{array}$ & $\begin{array}{l}H=2,93 ; \\
p>0,05\end{array}$ \\
\hline
\end{tabular}


був найвищим у хворих на ЦД2, ожиріння та АГ і достовірно відрізнявся на 24,4 \% від досліджуваного показника в 1-й дослідній групі. Рівень сечової кислоти був вірогідно більшим у хворих на ЦД2 та ожиріння (на 175,9 \%) та у пацієнтів 3 поєднаним перебігом Цд2, ожиріння та АГ (на 93,0 \%) стосовно даних у пацієнтів із ЦД2 і нормальною масою тіла (табл. 8).

Отримані дані свідчать про те, що у хворих 3 коморбідним перебігом ЦД2, ожиріння та АГ порушується срункція печінки та нирок. Діабетична нефропатія $€$ однією з найбільш поширених причин АГ у пацієнтів із ЦД2. Цукровий діабет 2 типу та інсулінорезистентність можуть стимулювати симпатичну нервову систему і ренінангіотензинову систему та сприяти затримці іонів натрію [24]. Також ЦД2 асоціюється $з$ посиленою проліферацією гладком'язових клітин судин. При підвищенні АТ і рівня глюкози у крові можливим $€$ ушкодження ендотеліальних клітин серця та, у кінцевому результаті, окиснювальне ушкодження [25] $з$ порушенням детоксикаційної функції печінки.

Аналіз показників вуглеводного обміну показав, що рівні глюкози, інсуліну та індекс НОМА у крові пацієнтів різних дослідних груп вірогідно різнилися при проведенні аналізу рангових варіацій Краскела - Уолліса. При цьому концентрація глюкози була найбільшою у хворих на ЦД2 з нормальною масою тіла в поєднанні з АГ, достовірно перевищуючи на 25,1 \% дані у пацієнтів з надмірною масою тіла, ЦД2 та АГ. Рівень інсуліну був вірогідно більшим у 5-й дослідній групі (у хворих на ЦД2 з надмірною масою тіла в поєднанні з АГ) стосовно даних 1-ї (на 42,8 \%) і 4-ї (на 19,7 \%) груп. Індекс НОМА у хворих 3

Таблиця 8 - Показники біохімічного аналізу крові у хворих на цукровий діабет 2 типу в поєднанні з надмірною масою тіла/ожирінням та артеріальною гіпертензією

\begin{tabular}{|c|c|c|c|c|c|c|c|}
\hline \multirow[b]{3}{*}{ Показник } & \multicolumn{6}{|c|}{ ГГрупа хворих } & \multirow{3}{*}{$\begin{array}{c}\text { Критерій } \\
\text { Краскела- } \\
\text { Уолліса }\end{array}$} \\
\hline & 1-ша & 2-га & 3-тя & 4-та & 5-та & 6-та & \\
\hline & $\begin{array}{c}\text { ЦД2+ } \\
\text { Норм МТ } \\
(\mathrm{n}=39)\end{array}$ & $\begin{array}{c}\text { ЦД2+ } \\
\text { Надм Мт } \\
(\mathrm{n}=33)\end{array}$ & $\begin{array}{c}\text { ЦД2+Ож } \\
(\mathrm{n}=22)\end{array}$ & $\begin{array}{c}\text { ЦД2+ } \\
\text { Норм MТ+ } \\
\text { АГ }(\mathrm{n}=59)\end{array}$ & $\begin{array}{c}\text { ЦД2+ } \\
\text { Надм МТ+ } \\
\text { АГ }(\mathrm{n}=131)\end{array}$ & $\begin{array}{c}\text { ЦД2+ } \\
\text { Ож+АГ } \\
(n=295)\end{array}$ & \\
\hline $\begin{array}{l}\text { Білок загальний, } \\
\text { г/л }\end{array}$ & $69(66 ; 74)$ & $70(67 ; 74)$ & $73(67 ; 77)$ & $69(65 ; 74)$ & $71(69 ; 76)$ & $72(68 ; 75)$ & $\begin{array}{l}H=4,16 \\
p>0,05\end{array}$ \\
\hline $\begin{array}{l}\text { Аланінамінотран- } \\
\text { сорераза, Од/л }\end{array}$ & $\begin{array}{c}15,2 \\
(12,0 ; 32,8) \\
\end{array}$ & $\begin{array}{c}19,6 \\
(12,7 ; 29,1)\end{array}$ & $\begin{array}{c}21,3 \\
(13,3 ; 45,5) \\
\end{array}$ & $\begin{array}{c}19,0 \\
(11,2 ; 27,2) \\
\end{array}$ & $\begin{array}{c}18,2 \\
(13,3 ; 27,3) \\
\end{array}$ & $\begin{array}{c}21,1 \\
(15,1 ; 31,8)\end{array}$ & $\begin{array}{c}H=10,24 \\
p>0,05\end{array}$ \\
\hline $\begin{array}{l}\text { Аспартатаміно- } \\
\text { транссрераза, Од/л }\end{array}$ & $\begin{array}{c}18,8 \\
(13,1 ; 30,0)\end{array}$ & $\begin{array}{c}16,5 \\
(14,5 ; 21,0)\end{array}$ & $\begin{array}{c}21,1 \\
(14,1 ; 39,7)\end{array}$ & $\begin{array}{c}17,8 \\
(14,1 ; 27,9)\end{array}$ & $\begin{array}{c}16,6 \\
(14,0 ; 24,8)\end{array}$ & $\begin{array}{c}18,5 \\
(14,4 ; 27,1)\end{array}$ & $\begin{array}{l}\mathrm{H}=4,57 \\
\mathrm{p}>0,05\end{array}$ \\
\hline $\begin{array}{l}\text { Загальний біліру- } \\
\text { бін, мкмоль/л }\end{array}$ & $\begin{array}{c}8,3 \\
(5,9 ; 11,8)\end{array}$ & $\begin{array}{c}8,2 \\
(4,5 ; 12,7)\end{array}$ & $\begin{array}{c}9,1 \\
(7,2 ; 14,2)\end{array}$ & $\begin{array}{c}6,7 \\
(5,2 ; 11,1)\end{array}$ & $\begin{array}{c}9,4 \\
(6,3 ; 13,8)\end{array}$ & $\begin{array}{c}9,2 \\
(6,4 ; 13,8)\end{array}$ & $\begin{array}{c}\mathrm{H}=13,21 ; \\
\mathrm{p}<0,05 ; \\
\mathrm{p}_{4-6}<0,05^{*}\end{array}$ \\
\hline $\begin{array}{l}\text { Гамма-глу } \\
\text { трансорер }\end{array}$ & $20(11 ; 20)$ & $21(13 ; 34)$ & $63(33 ; 90)$ & $21(16 ; 54)$ & $29(17 ; 54)$ & $35(21 ; 53)$ & $\begin{array}{l}H=10,75 \\
p>0,05\end{array}$ \\
\hline $\begin{array}{l}\text { Лужна фоссратаза, } \\
\text { Од/л }\end{array}$ & $\begin{array}{c}98 \\
(77 ; 119)\end{array}$ & $\begin{array}{c}75 \\
(74 ; 104)\end{array}$ & $\begin{array}{c}83 \\
(73 ; 91)\end{array}$ & $\begin{array}{c}80 \\
(65 ; 83)\end{array}$ & $\begin{array}{c}85 \\
(70 ; 104)\end{array}$ & $\begin{array}{c}72 \\
(57 ; 90)\end{array}$ & $\begin{array}{l}H=3,62 ; \\
p>0,05\end{array}$ \\
\hline $\begin{array}{l}\text { Амілаза загальна, } \\
\text { Од/л }\end{array}$ & $42(31 ; 59)$ & $60(35 ; 81)$ & $47(38 ; 55)$ & $40(35 ; 66)$ & $42(34 ; 74)$ & $43(30 ; 59)$ & $\begin{array}{l}\mathrm{H}=0,64 ; \\
\mathrm{p}>0,05\end{array}$ \\
\hline $\begin{array}{l}\text { Панкреатична } \\
\alpha \text {-амілаза, Од/л }\end{array}$ & $\begin{array}{c}13,5 \\
(9,1 ; 26,2)\end{array}$ & $\begin{array}{c}23,2 \\
(14,6 ; 87,0)\end{array}$ & $\begin{array}{c}21,2 \\
(14,0 ; 26,9)\end{array}$ & $\begin{array}{c}4,4 \\
(2,7 ; 9,4)\end{array}$ & $\begin{array}{c}14,7 \\
(12,6 ; 21,3)\end{array}$ & $\begin{array}{c}18,6 \\
(16,5 ; 33,9)\end{array}$ & $\begin{array}{l}H=2,10 \\
p>0,05\end{array}$ \\
\hline $\begin{array}{l}\text { Сечовина, } \\
\text { ммоль/л }\end{array}$ & $\begin{array}{c}4,5 \\
(3,4 ; 6,3)\end{array}$ & $\begin{array}{c}5,2 \\
(4,7 ; 6,9)\end{array}$ & $\begin{array}{c}4,9 \\
(3,6 ; 6,0)\end{array}$ & $\begin{array}{c}5,1 \\
(4,2 ; 6,2)\end{array}$ & $\begin{array}{c}5,5 \\
(4,4 ; 6,9)\end{array}$ & $\begin{array}{c}5,6 \\
(4,5 ; 7,0)\end{array}$ & $\begin{array}{c}\mathrm{H}=16,07 ; \\
\mathrm{p}<0,05^{\star} ; \\
\mathrm{p}_{1-6}<0,05^{*}\end{array}$ \\
\hline $\begin{array}{l}\text { Креатинін, } \\
\text { мкмоль/л }\end{array}$ & $66(56 ; 75)$ & $68(58 ; 81)$ & $77(55 ; 87)$ & $71(55 ; 85)$ & $70(61 ; 85)$ & $72(61 ; 85)$ & $\begin{array}{l}H=7,82 \\
p>0,05\end{array}$ \\
\hline $\begin{array}{l}\text { Сечова кислота, } \\
\text { ммоль/л }\end{array}$ & $\begin{array}{c}158 \\
(141 ; 175)\end{array}$ & $\begin{array}{c}258 \\
(206 ; 343)\end{array}$ & $\begin{array}{c}436 \\
(343 ; 515)\end{array}$ & $\begin{array}{c}240 \\
(179 ; 410)\end{array}$ & $\begin{array}{c}273 \\
(220 ; 349)\end{array}$ & $\begin{array}{c}305 \\
(247 ; 401)\end{array}$ & $\begin{array}{c}\mathrm{H}=11,41 ; \\
\mathrm{p}<0,05^{\star} \\
\mathrm{p}_{1-3}<0,05^{\star} \\
\mathrm{p}_{1-6}<0,05^{\star}\end{array}$ \\
\hline К, ммоль/л & $\begin{array}{c}4,97 \\
(4,50 ; 5,17)\end{array}$ & $\begin{array}{c}4,90 \\
(4,57 ; 5,39)\end{array}$ & $\begin{array}{c}4,91 \\
(4,68 ; 5,35)\end{array}$ & $\begin{array}{c}4,47 \\
(4,23 ; 4,88)\end{array}$ & $\begin{array}{c}4,86 \\
(4,43 ; 5,18)\end{array}$ & $\begin{array}{c}4,78 \\
(4,49 ; 5,10)\end{array}$ & $\begin{array}{l}H=9,37 \\
p>0,05\end{array}$ \\
\hline $\mathrm{Na}, \mathrm{N}$ & $\begin{array}{c}140 \\
(140 ; 141)\end{array}$ & $\begin{array}{c}139 \\
(134 ; 141)\end{array}$ & $\begin{array}{c}144 \\
(134 ; 146)\end{array}$ & $\begin{array}{c}140 \\
(137 ; 142)\end{array}$ & $\begin{array}{c}140 \\
(137 ; 142)\end{array}$ & $\begin{array}{c}139 \\
(137 ; 142)\end{array}$ & $\begin{array}{l}H=2,89 ; \\
p>0,05\end{array}$ \\
\hline Сl, ммоль/л & $\begin{array}{c}107,1 \\
(102,3 ; \\
107,1) \\
\end{array}$ & $\begin{array}{c}99,9 \\
(99,0 ; \\
104,4)\end{array}$ & $\begin{array}{c}108,9 \\
(106,7 ; \\
111,1)\end{array}$ & $\begin{array}{l}103,2 \\
(100,4 ; \\
106,0)\end{array}$ & $\begin{array}{c}103,8 \\
(101,2 ; \\
105,7) \\
\end{array}$ & $\begin{array}{l}101,3 \\
(99,0 ; \\
103,2)\end{array}$ & $\begin{array}{c}\mathrm{H}=12,34 \\
\mathrm{p}>0,05\end{array}$ \\
\hline $\mathrm{Ca}, \mathrm{Mm}$ & $\begin{array}{c}2,31 \\
(2,19 ; 2,34) \\
\end{array}$ & $\begin{array}{c}2,37 \\
(2,30 ; 2,42) \\
\end{array}$ & $\begin{array}{c}2,35 \\
(2,25 ; 2,49) \\
\end{array}$ & $\begin{array}{c}2,31 \\
(2,27 ; 2,37) \\
\end{array}$ & $\begin{array}{c}2,34 \\
(2,28 ; 2,42) \\
\end{array}$ & $\begin{array}{c}2,34 \\
(2,28 ; 2,41) \\
\end{array}$ & $\begin{array}{l}\mathrm{H}=3,89 \\
\mathrm{p}>0,05\end{array}$ \\
\hline
\end{tabular}


коморбідним перебігом ЦД2 з надмірною масою тіла/ожирінням та АГ був достовірно вищим щодо даних у пацієнтів із ЦД2 та нормальною масою тіла, зокрема, на 22,7 \% у 5-й групі й на
22,1 \% - у 6-й (табл. 9). При зіставленні показників вуглеводного обміну в 5-й і 6-й дослідних групах вірогідної різниці у величинах не спостерігали.

Таблиця 9 - Показники вуглеводного обміну у хворих різних груп

\begin{tabular}{|c|c|c|c|c|c|}
\hline \multicolumn{2}{|r|}{ Група хворих } & \multirow{2}{*}{$\begin{array}{c}\text { Глюкоза, } \\
\text { ммоль/л }\end{array}$} & \multirow{2}{*}{$\begin{array}{c}\text { HbA1c, } \\
\% \\
9,10 \\
(7,70 ; 11,82)\end{array}$} & \multirow{2}{*}{$\begin{array}{c}\begin{array}{c}\text { Інсулін, } \\
\text { мкОд/мл }\end{array} \\
10,35 \\
(6,74 ; 15,47)\end{array}$} & \multirow{2}{*}{$\begin{array}{c}\text { Індекс НОМА, } \\
\text { од. } \\
4,75 \\
(3,15 ; 6,07)\end{array}$} \\
\hline 1-ша & ЦД2+Норм МТ (n=39) & & & & \\
\hline 2-га & ЦД2+Надм МТ (n=33) & $\begin{array}{c}10,50 \\
(8,20 ; 13,57)\end{array}$ & $\begin{array}{c}8,60 \\
(7,30 ; 9,40)\end{array}$ & $\begin{array}{c}14,35 \\
(9,11 ; 16,61)\end{array}$ & $\begin{array}{c}5,79 \\
(4,79 ; 7,77)\end{array}$ \\
\hline ||3-тя & ЦД2+Ож (n=22) & $\begin{array}{c}9,49 \\
(6,98 ; 11,60)\end{array}$ & $\begin{array}{c}8,35 \\
(6,80 ; 9,20)\end{array}$ & $\begin{array}{c}13,45 \\
(7,79 ; 18,31)\end{array}$ & $\begin{array}{c}4,89 \\
(4,01 ; 6,16)\end{array}$ \\
\hline 4-та & ЦД2+Норм МТ+АГ (n=59) & $\begin{array}{c}10,45 \\
(8,20 ; 13,70)\end{array}$ & $\begin{array}{c}8,70 \\
(7,55 ; 10,03)\end{array}$ & $\begin{array}{c}12,35 \\
(8,10 ; 15,87)\end{array}$ & $\begin{array}{c}5,18 \\
(4,31 ; 6,94)\end{array}$ \\
\hline 5-та & ЦД2+Надм МТ+АГ (n=131) & $\begin{array}{c}8,35 \\
(7,10 ; 11,36) \\
\end{array}$ & $\begin{array}{c}8,60 \\
(7,50 ; 10,10)\end{array}$ & $\begin{array}{c}14,78 \\
(11,37 ; 18,52)\end{array}$ & $\begin{array}{c}5,83 \\
(4,86 ; 6,89) \\
\end{array}$ \\
\hline 6-та & ЦД2+Ож+АГ (n=295) & $\begin{array}{c}9,37 \\
(7,74 ; 11,80)\end{array}$ & $\begin{array}{c}8,40 \\
(7,30 ; 9,50)\end{array}$ & $\begin{array}{c}13,94 \\
(10,25 ; 17,10)\end{array}$ & $\begin{array}{c}5,80 \\
(4,62 ; 6,95)\end{array}$ \\
\hline \multicolumn{2}{|c|}{ Критерій Краскела - Уолліса } & $\begin{array}{l}H=14,35 \\
p=0,014^{*}\end{array}$ & $\begin{array}{l}\mathrm{H}=10,47 \\
\mathrm{p}=0,063\end{array}$ & $\begin{array}{l}\mathrm{H}=21,17 \\
\mathrm{p}<0,001^{*}\end{array}$ & $\begin{array}{l}\mathrm{H}=18,98 \\
\mathrm{p}=0,002^{*}\end{array}$ \\
\hline \multicolumn{2}{|l|}{$p$} & $\mathrm{p}_{4-5}<0,05^{\star}$ & - & $\begin{array}{l}\mathrm{p}_{1-5}<0,05^{\star} ; \\
\mathrm{p}_{4-5}<0,05^{\star}\end{array}$ & $\begin{array}{l}\mathrm{p}_{1-5}<0,05^{*} ; \\
\mathrm{p}_{1-6}<0,05^{*}\end{array}$ \\
\hline
\end{tabular}

Примітка. * - статистично достовірні результати.

ВИСНОВКИ. 1. Під час аналізу статевого диморфізму встановлено переважання осіб жіночої статі 3 коморбідним перебігом цукрового діабету 2 типу з надмірною масою тіла/ожирінням та артеріальною гіпертензією. При цьому серед хворих на цукровий діабет 2 типу з коморбідною артеріальною гіпертензією виявлено вірогідно вищий відсоток хворих чоловіків 3 нормальною масою тіла.

2. При аналізі антропометричних показників хворих різних груп встановлено, що у пацієнтів 6-ї групи зріст був вірогідно меншим стосовно даних у хворих на цукровий діабет 2 типу з нормальною масою тіла та при поєднанні з артеріальною гіпертензією. Індекс маси тіла був достовірно вищим у пацієнтів з надмірною масою тіла/ожирінням.

3. У хворих з коморбідним перебігом цукрового діабету 2 типу 3 надмірною масою тіла/ ожирінням та артеріальною гіпертензією встановлено вірогідно вищі рівні сечовини (на 24,4 \%) та сечової кислоти (на 93,0 \%) щодо даних у пацієнтів із цукровим діабетом 2 типу та нормальною масою тіла.

\section{СПИСОК ЛІТЕРАТУРИ}

1. Rate of blood pressure control and antihypertensive treatment approaches in diabetic patients with hypertension / N. Kahya Eren, E. Harman, D. Dolek [et al.] // Turk Kardiyol Dern Ars. -2014. - 42, No. 8. - P. 733-740.

2. Blood pressure lowering in type 2 diabetes: a systematic review and meta-analysis / C. A. Emdin, K. Rahimi, B. Neal [et al.] // JAMA. -2015. -313, No. 6. P. 603-615.

3. Cardiovascular outcomes in framingham participants with diabetes: the importance of blood pressure / G. Chen, F. A. McAlister, R. L. Walker [et al.] // Hypertension. - 2011. - 57, No. 5. - P. 891-897.

4. Nouh F. Prevalence of hypertension among diabetic patients in Benghazi: a study of associated factors /
F. Nouh, M. Omar, M. Younis // Asian J. Med. Heal. 2017. - 6 (4). - P. 1-11. DOI:10.9734/AJMAH/2017/35830

5. Vargas-Uricoechea $\mathrm{H}$. Control of blood pressure and cardiovascular outcomes in type 2 diabetes / H. Vargas-Uricoechea, M. F. Caceres-Acosta // Open Med. (Wars). - 2018. - 13. - P. 304-323.

6. Akalu Y. Hypertension and its associated factors among type 2 diabetes mellitus patients at Debre Tabor General Hospital, Northwest Ethiopia / Y. Akalu, Y. Belsti // Diabetes Metab. Syndr. Obes. - 2020. - 13. P. 1621-1631.

7. Urinary protein excretion is associated with left ventricular hypertrophy in treatment-naive hypertensive patients in an african hospital setting / A. Forlemu, 
A. Menanga, G. Ashuntantang, S. Kingue // Cardiorenal Med. - 2013. - 3, No. 1. - P. 57-62.

8. ECG strain pattern in hypertension is associated with myocardial cellular expansion and diffuse interstitial fibrosis: a multi-parametric cardiac magnetic resonance study / J. C. Rodrigues, A. M. Amadu, A. Ghosh Dastidar [et al.] // Eur. Heart J. Cardiovasc Imaging. - 2017. - 18, No. 4. - P. 441-450.

9. American Diabetes Association. Standards of Medical Care in Diabetes-2019 Abridged for Primary Care Providers / American Diabetes Association // Clin. Diabetes. - 2019. - 37, No. 1. - P. 11-34.

10. 2018 ESC/ESH Guidelines for the management of arterial hypertension / B. Williams, G. Mancia, W. Spiering [et al.] // Eur. Heart J. - 2018. - 39, No. 33. P. 3021-3104.

11. Body Mass Index: Considerations for Practitioners [Електронний ресурc]-Access mode : https://www.cdc. gov/obesity/downloads/bmiforpactitioners.pdf

12. Mansour A. A. Prevalence and control of hypertension in iraqi diabetic patients: a prospective cohort study / A. A. Mansour // Open Cardiovasc. Med. J. - 2012. - 6. - P. 68-71.

13. Mengesha A. Y. Hypertension and related risk factors in type 2 diabetes mellitus (DM) patients in Gaborone City Council (GCC) clinics, Gaborone, Botswana / A. Y. Mengesha // Afr. Health Sci. - 2007. - 7, No. 4. P. 244-245

14. Self-rated health and the risk of incident type 2 diabetes mellitus: A cohort study / J. W. Noh, Y. Chang M. Park [et al.] // Sci. Rep. - 2019. - 9, No. 1. - P. 3697

15. Alice Y. Canadian diabetes association clinical practice guidelines expert committee / Y. Alice // Can. J. Diabetes. - 2019. - 37, No. 2013. - P. 1-3.

16. Head T. The aging risk and atherosclerosis: A fresh look at arterial homeostasis / T. Head, S. Daunert, P. J. Goldschmidt-Clermont // Front Genet. -2017. - 8. P. 216.

\section{REFERENCES}

1. Kahya Eren, N., Harman, E., Dolek, D., Tutuncuoglu, A.P., Emren, S.V., Levent, F., ... Nazli, C. (2014). Rate of blood pressure control and antihypertensive treatment approaches in diabetic patients with hypertension. Turk Kardiyol. Dern. Ars., 42 (8), 733-740. DOI:10.5543/tkda.2014.53384

2. Emdin, C.A., Rahimi, K., Neal, B., Callender, T., Perkovic, V., \& Patel, A. (2015). Blood pressure lowering in type 2 diabetes: a systematic review and meta-analysis. JAMA, 313 (6), 603-615. DOI:10.1001/jama.2014.18574

3. Chen, G., McAlister, F.A., Walker, R.L., Hemmelgarn, B.R., \& Campbell, N.R. (2011). Cardiovascular outcomes in framingham participants with diabetes: the importance of blood pressure. Hypertension, 57 (5), 891 897. DOI:10.1161/HYPERTENSIONAHA.110.162446

4. Nouh, F., Omar, M., \& Younis, M. (2017). Prevalence of hypertension among diabetic patients in Benghazi: a study of associated factors. Asian J. Med. Heal., 6 (4), 1-11. DOI:10.9734/AJMAH/2017/35830
17. Kohn J. C. Age-related vascular stiffening: causes and consequences / J. C. Kohn, M. C. Lampi, C. A. Reinhart-King // Front Genet. - 2015. - 6. - P. 112.

18. Arnetz L. Sex differences in type 2 diabetes: focus on disease course and outcomes / L. Arnetz, N. R. Ekberg, M. Alvarsson // Diabetes Metab. Syndr. Obes. - 2014. 7. - P. 409-420.

19. Sattar N. Gender aspects in type 2 diabetes mellitus and cardiometabolic risk / N. Sattar // Best Pract. Res. Clin. Endocrinol. Metab. - 2013. - 27, No. 4. P. 501-507.

20. Type 2 diabetes from pediatric to geriatric age: analysis of gender and obesity among 120,183 patients from the German/Austrian DPV database / W. L. Awa, E. Fach, D. Krakow [et al.] // Eur. J. Endocrinol. - 2012. 167, No. 2. - P. 245-254.

21. Gender-specific care of the patient with diabetes: review and recommendations / M. J. Legato, A. Gelzer, R. Goland [et al.] // Gend. Med. - 2006. - 3, No. 2. P. 131-158.

22. Szalat A. Gender-specific care of diabetes mellitus: particular considerations in the management of diabetic women / A. Szalat, I. Raz // Diabetes Obes. Metab. - 2008. - 10, No. 12. - P. 1135-1156.

23. Diabetes as a risk factor for myocardial infarction: population and gender perspectives / V. Lundberg, B. Stegmayr, K. Asplund [et al.] // J. Intern. Med. - 1997. 241, No. 6. - P. 485-492.

24. Hypertension and antihypertensive therapy as risk factors for type 2 diabetes mellitus. Atherosclerosis risk in communities study / T. W. Gress, F. J. Nieto, E. Shahar [et al.] // N. Engl. J. Med. - 2000. - 342, No. 13. - P. 905-912.

25. Lago R. M. Diabetes and hypertension / R. M. Lago, P. P. Singh, R. W. Nesto // Nat. Clin. Pract. Endocrinol. Metab. - 2007. -3, No. 10. - P. 667.

5. Vargas-Uricoechea, H., \& Caceres-Acosta, M.F. (2018). Control of blood pressure and cardiovascular outcomes in type 2 diabetes. Open Med. (Wars), 13, 304-323. DOI:10.1515/med-2018-0048

6. Akalu, Y., \& Belsti, Y. (2020). Hypertension and its associated factors among type 2 diabetes mellitus patients at Debre Tabor General Hospital, Northwest Ethiopia. Diabetes Metab. Syndr. Obes., 13, 1621-1631. DOI:10.2147/DMSO.S254537

7. Forlemu, A., Menanga, A., Ashuntantang, G., \& Kingue, S. (2013). Urinary protein excretion is associated with left ventricular hypertrophy in treatment-naive hypertensive patients in an african hospital setting. Cardiorenal Med., 3 (1), 57-62. DOI:10.1159/000349938

8. Rodrigues, J.C., Amadu, A.M., Ghosh Dastidar, A., McIntyre, B., Szantho, G.V., Lyen, S., ... BucciarelliDucci, C. (2017). ECG strain pattern in hypertension is associated with myocardial cellular expansion and diffuse interstitial fibrosis: a multi-parametric cardiac magnetic 
resonance study. Eur. Heart J. Cardiovasc. Imaging, 18 (4), 441-450. DOI:10.1093/ehjci/jew117

9. American Diabetes, A. (2019). Standards of medical care in diabetes-2019 abridged for primary care providers. Clin. Diabetes, 37 (1), 11-34. DOI:10.2337/ cd18-0105

10. Williams, B., Mancia, G., Spiering, W., Agabiti Rosei, E., Azizi, M., Burnier, M., ... Group, E.S.C.S.D. (2018). 2018 ESC/ESH Guidelines for the management of arterial hypertension. Eur. Heart J., 39 (33), 3021-3104. DOI:10.1093/eurheartj/ehy339

11. Body Mass Index: Considerations for Practitioners. Retrieved from: https://www.cdc.gov/obesity/downloads/ bmiforpactitioners.pdf

12. Mansour, A.A. (2012). Prevalence and control of hypertension in iraqi diabetic patients: a prospective cohort study. Open Cardiovasc. Med. J., 6, 68-71. DOI:10.2174/1874192401206010068

13. Mengesha, A.Y. (2007). Hypertension and related risk factors in type 2 diabetes mellitus (DM) patients in Gaborone City Council (GCC) clinics, Gaborone, Botswana. Afr. Health Sci., 7 (4), 244-245.

14. Noh, J.W., Chang, Y., Park, M., Kwon, Y.D., \& Ryu, S. (2019). Self-rated health and the risk of incident type 2 diabetes mellitus: A cohort study. Sci. Rep., 9 (1), 3697. DOI:10.1038/s41598-019-40090-y

15. Alice, Y. (2019). Canadian diabetes association clinical practice guidelines expert committee. Can. J. Diabetes, 37 (2013), 1-3.

16. Head, T., Daunert, S., \& Goldschmidt-Clermont, P.J. (2017). The aging risk and atherosclerosis: A fresh look at arterial homeostasis. Front Genet., 8, 216. DOI:10.3389/fgene.2017.00216

17. Kohn, J.C., Lampi, M.C., \& Reinhart-King, C.A. (2015). Age-related vascular stiffening: causes and consequences. Front Genet., 6, 112. DOI:10.3389/fgene. 2015.00112
18. Arnetz, L., Ekberg, N.R., \& Alvarsson, M. (2014). Sex differences in type 2 diabetes: focus on disease course and outcomes. Diabetes Metab. Syndr. Obes., 7, 409-420. DOI:10.2147/DMSO.S51301

19. Sattar, N. (2013). Gender aspects in type 2 diabetes mellitus and cardiometabolic risk. Best Pract. Res. Clin. Endocrinol. Metab., 27 (4), 501-507. DOI:10.1016/j.beem.2013.05.006

20. Awa, W.L., Fach, E., Krakow, D., Welp, R., Kunder, J., Voll, A., ... German BMBF Competence Networks Diabetes mellitus and Obesity. (2012). Type 2 diabetes from pediatric to geriatric age: analysis of gender and obesity among 120,183 patients from the German/ Austrian DPV database. Eur. J. Endocrinol., 167 (2), 245-254. DOI:10.1530/EJE-12-0143

21. Legato, M.J., Gelzer, A., Goland, R., Ebner, S.A., Rajan, S., Villagra, V., ... Writing Group for The Partnership for Gender-Specific, M. (2006). Gender-specific care of the patient with diabetes: review and recommendations. Gend. Med., 3 (2), 131-158. DOI:10.1016/s15508579(06)80202-0

22. Szalat, A., \& Raz, I. (2008). Gender-specific care of diabetes mellitus: particular considerations in the management of diabetic women. Diabetes Obes. Metab., 10 (12), 1135-1156. DOI:10.1111/j.1463-1326.2008.00896.x

23. Lundberg, V., Stegmayr, B., Asplund, K., Eliasson, M., \& Huhtasaari, F. (1997). Diabetes as a risk factor for myocardial infarction: population and gender perspectives. Journal of Internal Medicine, 241 (6), 485492. https://doi.org/10.1111/j.1365-2796.1997.tb00006.x

24. Gress, T.W., Nieto, F.J., Shahar, E., Wofford, M.R., \& Brancati, F.L. (2000). Hypertension and antihypertensive therapy as risk factors for type 2 diabetes mellitus. Atherosclerosis risk in communities study. N. Engl. J. Med., 342 (13), 905-912. DOI:10.1056/NEJM200003303421301

25. Lago, R.M., Singh, P.P., \& Nesto, R.W. (2007). Diabetes and hypertension. Nat. Clin. Pract. Endocrinol. Metab., 3 (10), 667. DOI:10.1038/ncpendmet0638

\section{CLINICAL AND LABORATORY CHARACTERISTICS OF COMORBID COURSE TYPE 2 DIABETES MELLITUS WITH OVERWEIGHT/OBESITY AND ARTERIAL HYPERTENSION}

\section{Summary}

Introduction. Arterial hypertension $(\mathrm{AH})$ is the leading cause of morbidity and mortality in patients with type 2 diabetes mellitus (T2DM), which is associated with cardiovascular disease.

The aim of the study - to analyze the main clinical and laboratory factors of comorbid type 2 diabetes mellitus with overweight/obesity and hypertension.

Research Methods. A retrospective analysis of medical records was performed in 579 patients with type 2 diabetes mellitus (T2DM). The concentration of glucose and other biochemical parameters were determined using a standard kit on an automatic biochemical analyzer "COBAS INTEGRA® 400" (Roche Diagnostics). General blood counts were determined on an automatic hematology analyzer "Yumizen H500 CT".

Results and Discussion. The analysis of Kraskel-Wallis rank variations did not reveal the diagnostic value of general blood and urine tests in the diagnosis of comorbid course of diabetes mellitus, overweight/obesity and hy- 
pertension. The analysis of biochemical parameters revealed the highest levels of urea and uric acid in patients with diabetes mellitus, obesity and hypertension. Analysis of carbohydrate metabolism showed that the level of glucose, insulin and HOMA-index in the blood of patients from different experimental groups probably differed when analyzing the rank variations of Kraskel-Wallis.

Conclusions. The analysis of sexual dimorphism revealed a predominance of females with comorbid type 2 diabetes, overweight/obesity and hypertension. At the same time, among patients with type 2 diabetes mellitus with comorbid arterial hypertension, a significantly higher percentage of sick men with normal body weight was found. In the analysis of anthropometric parameters of patients of different groups, it was found that in patients of group 6 the growth was probably lower than in patients with T2DM with normal body weight and in combination with $A H$. BMI was likely to be higher in overweight/obese patients. Patients with comorbid type 2 diabetes, overweight/obesity, and arterial hypertension had significantly higher levels of urea (24.4\%) and uric acid (93.0 \%) compared to patients with diabetes mellitus type 2 and normal body weight.

KEY WORDS: type 2 diabetes mellitus; overweight/obesity; arterial hypertension; comorbidity; hemogram; general urine analysis; biochemical parameters.

Отримано 23.09.21

Адреса для листування: М. І. Марущак, Тернопільський національний медичний університет імені І. Я. Горбачевського моз України, майдан Волі, 1, Тернопіль, 46001, Україна, e-mail: marushchak@tdmu.edu.ua. 